https://doi.org/10.48009/2_iis_2009_571-584

\title{
THE IMPACT OF THE BALANCED SCORECARD ON GOVERNMENT-TO-GOVERNMENT E-SERVICE DELIVERY
}

\author{
Assion Lawson-Body, University of North Dakota, assion.lawsonbody@mail.business.und.edu \\ Lori Willoughby, Minot State University, Lori.Willoughby @minotstateu.edu
}

\begin{abstract}
The application of the Balanced Scorecard (BSC) in the private business sector is well known and documented. But, very little research has been reported regarding the adaptation or the application of the BSC to e-government service delivery performance. This paper addresses the issue of delivering e-government services using the concept of an accepted management tool, the BSC. $A$ research model, based on government-togovernment $(G 2 G)$ is developed to match potential benefits of the usability of website-supported BSC's four dimensions (innovation and learning, internal business process, customer, and financial) in improving e-government service delivery performance. The study used content analysis to analyze the data obtained from a sample of 19 county veteran service officers (CVSOs) to test the hypotheses. The results show that websitesupported BSC three perspectives (learning and innovation, internal process, and veteran value proposition) have a positive impact on $e$ government service delivery performance. The effectiveness of website-supported financial perspectives has a negative impact on $e$ government service delivery performance in the early stage of the implementation of the websites. However, as time goes by, that impact becomes positive because the high initial cost decreases over time. The implications of the results are discussed.
\end{abstract}

Keywords: E-Service, E-Government, Balanced Scorecard, Performance

\section{INTRODUCTION}

With the growth of the Internet, e-commerce has spread throughout the world. This trend is also seen in the public sector, where e-government applications are being developed $[18,5]$. Egovernment is more than just Web pages of government agencies and government officials using email, blogs or instant messaging through mobile devices. It also incorporates the delivery of

Volume X, No. 2, 2009 valuable services to citizens at a lower cost and usability capabilities as means to better governance

performance [16]. Public managers adopt the Internet because they believe that using it will enhance the overall performance of e-government service delivery through savings in cost and time.

Market research has indicated that the service delivery process has a significant impact on a company's financial performance [19]. Public sector performance measures are quantitative ways of determining the resources that go into providing services, the immediate results of those services, and the longer-term results of providing those services [18]. The traditional financial performance measures worked well for the industrial era, but they are out of step with the skills, knowledge, and competencies governments are trying to master today [12]. Although the application of the Balanced Scorecard (BSC) in the private business sector is well known and documented, there is a need for the application of the BSC to egovernment service delivery performance.

According to the Performance Institute (PI), Internet users who interact with government agencies can be classified in the following three major segments: 1) government-to-citizen (G2C); 2) government-to-business (G2B); 3) governmentto-government (G2G) [2]. Our definition of G2G is based on the assumption that the fundamental difference between $\mathrm{G} 2 \mathrm{G}$ and $\mathrm{G} 2 \mathrm{C}$ is the nature of the relationship [2]. In G2G e-government, the idea is to form a close relationship between two government agencies that will make complementary investments to enable one another's e-government strategy. The relation involves the adoption of similar standards, extensive intergovernment communication and collaboration, and joint information technology (IT) investment. In contrast, G2C e-government is characterized by arms-length relationships. While there may be elements of branding, citizen relationships, and 
personalization, there is no mutual investment in IT or communication. The only investments required by the citizen are a PC and an Internet connection, which are both completely general tools [2].

This study will focus on the users who are in the G2G categories that deal with the way partner government agencies access services or integrate services across agency organizational boundaries through technologies [2]. This research also focuses on government websites used by county veteran service officers (CVSOs) to interact with other government agencies in order to deliver electronic services to veterans. The relationship is between CVSOs and other government units or agencies.

The objective of this paper is to address the issue of delivering electronic services using the concept of an accepted management tool--the BSC. In other words, the BSC may be used to identify the strategic impacts of CVSO's usability of websites on e-government service delivery performance. The CVSOs assist all veterans and their dependents in obtaining all benefits to which they are entitled, both federal and state. The CVSOs are chosen because they play the role of intermediary among veterans, veteran benefits providers, and government agencies. CVSOs interact on a G2G and $\mathrm{G} 2 \mathrm{C}$ basis in order to serve veterans.

This paper is organized as follows. Section II contains an in depth description of the BSC theory. In Section III, e-government service delivery performance is examined. In Section IV, the research model and the hypotheses are presented. The methodology and the multiple case studies are outlined in section V. Section VI elaborates on the results. Section VII presents the conclusion of the paper.

\section{BALANCED SCORECARD AS AN IT PERFORMANCE MANAGEMENT TOOL}

To understand Compaq's financial success better, Wright et al., [20] used the BSC to develop a causal model of firm performance that highlights the contribution of IT to four different dimensions of that performance. They found that IT, along with process reengineering, when properly aligned with Compaq's business strategy, contributed substantially to Compaq's overall success and market share.

Huang and $\mathrm{Hu}[10]$ have developed a framework to address the issue of deploying Web services strategically using the BSC. The Web services BSC framework developed by Huang and $\mathrm{Hu}$ [10], subscribing to the BSC theory of business, emphasizes the critical issue of how Web services technology can be integrated into a firm's competitive strategy to deliver results where they are desirable, measurable, and beneficial to the firm's strategy.

The BSC consists of a set of measures that gives business executives a fast but comprehensive view of the whole company [12]. The BSC includes financial measures that show the results of actions already taken and it complements the financial measures with operational measures that are the drivers of future financial performance [12]. The BSC is a multi-dimensional performance measurement system that encompasses financial and non-financial outcomes [19]. It provides causal links connecting the multiple classes of nonfinancial measure (drivers of the performance) and the financial measures (final outcome) [19].

In its original form, the BSC was designed to be a performance measurement tool, using four interrelated business perspectives: financial, customer, internal business process, and innovation and learning [10]. These fours factors are not isolated. They are linked in a causal relationship that leads, directly or indirectly, to the financial performance of the firm. Cause and effect linkages are identified from the execution of daily activities to eventual results. Performance measurements are considered from these four factors [20]. In the heart of the BSC concept is its theory of business: firms that continuously improve their capabilities for learning and innovation achieve better performance in their internal business processes which, in turn, leads to more effective execution of their customer value propositions and eventually results in sustained competitive advantage and improved financial performance [10].

Several companies have already adopted the BSC because the complexity of managing an organization requires that managers are able to view performance in different areas simultaneously [12]. Many companies designed the BSC to emphasize the attention of its top executives on a short list of critical indicators of current and future performance [12].

After applying the BSC to their business, some companies realized that it represents a fundamental change in the underlying assumptions about performance measurement [12]. The BSC puts 
strategy, not control, at the center [12]. In fact, Kaplan and Norton [20] developed the BSC to link a firm's strategic objectives to performance measurements. The BSC provides top executives and managers with a comprehensive vision that translates a firm's strategy objectives into a valuable set of performance measures [12]. It can serve as the focal point for the company's efforts, setting up priorities to managers, employees, investors and customers [11]. In fact, the BSC wasn't a replacement for financial measures like real option analysis (ROA); it was their complement [11]. The BSC allows some companies to introduce four new management processes (translating the vision, communicating and linking, business planning, and feedback and learning), separately and in combination, contribute to linking long-term strategic objectives with short-term actions [11]. Through the years, the BSC has evolved, from the performance measurement tool to a tool for implementing strategies [15]. This shift has prompted companies to view the BSC as a strategic communication and management system [15]. Many companies are adopting the BSC as a strategic management system [1]. Kaplan and Norton provide significant insight into the application potential of the BSC for private and public sector companies and give numerous design and implementation examples from a range of companies of any size [15]. Following Kaplan and Norton and many other authors, this paper complements past research studying e-government service delivery performance using the BSC.

\section{E-GOVERNMENT SERVICE DELIVERY PERFORMANCE}

E-government service delivery means the government's use of technology, particularly webbased Internet applications, to enhance the access to and delivery of information and service to employees and other government units [18, 14]. Performance measurement of e-government service deliveries is important so that a government can track what is working and what is not and assure citizens that the government's time and funds are being well spent [18]. E-government service typically is intangible in nature. As a result, the need of performance measurement systems at different levels of decision-making becomes critical.

Many authors have conducted empirical research and anecdotal studies on the concept of Egovernment which incurs costs but provides faster and convenient information access [16]. The
Malcolm Baldrige National Quality Award (MBNQA) is intended to provide a framework that could help companies achieve performance goals [16]. This framework and the DeLone and McLean's information systems (IS) Success model have been used to develop a theoretical model. After testing the model in an e-government environment, Prybutok et al., [16] found that both leadership and IT quality increased benefits and improved public service delivery through good websites. Gilbert et al., [8] found that trust, financial security, information quality, time, and money are predictors of e-government failure or success.

According to Gartner (2001), over the next two years 70 percent of governments that do not develop an e-government architecture will duplicate efforts and infrastructure, and will fail to meet constituent expectations for service delivery, resulting in complaints and wasted public funds [7]. Gassan et al., [7] mentioned that 15 percent of egovernment's benefits stem from technology solutions; the rest comes from streamlining the delivery of services. The two together can produce dramatic cost savings per transaction. On average, 40 percent of the expenditures of state governments in the United States pay for the delivery of services, so the potential savings are enormous. The savings come mostly from allowing the government to reduce the size of its workforce or to enhance service by redirecting employees to more valuable activities. Additional cost savings come from capturing information more accurately. Larsen and Rainie (cited in [2]) added that the use of government Web sites has been one of the most rapidly increasing user activities in the United States.

According to Larsen and Rainie, the use of government Web portals has been one of the most rapidly increasing user activities in the United States [2]. One of the more widespread electronic commerce approaches is the digital government service delivery, i.e., the use of Web portals to advertise, display and offer government services [4].

\section{THE RESEARCH MODEL AND HYPOTHESES DEVELOPMENT}

In the research model shown in Figure 1, the dependent variable will be drawn from egovernment service delivery performance. The independent variables will be drawn from the website-supported four interrelated BSC business 
perspectives. Because these four interrelated business perspectives are supported by websites used by CVSOs on a $\mathrm{G} 2 \mathrm{G}$ basis in order to serve veterans, they have been adapted as follows: website-supported innovation and learning perspective, website-supported internal process perspective, website-supported veteran value proposition perspective, and website-supported financial perspective. Each of them is discussed below.

\section{Website-Supported Innovation and Learning Perspective}

Learning is an organizational process dependent on communication, collaboration, cooperation, and employee interaction. Learning needs an organization to turn it into knowledge which has an impact on innovation. Knowledge interpretation leads to new understanding of the issues or concepts under study. By sharing individual employee knowledge in the organization, the knowledge of individual organization becomes organizational knowledge and arouses organizational innovation $[3,6]$. Managers in organizations need to transform their knowledge to form concepts and solve problems through the process of memorization, thinking, and learning [3, 6]. Effective learning process will generate more knowledge and create innovation. But to reduce information loading during the learning process, high quality Web sites should be used to provide easy access to the necessary information the managers can understand and share. The usability of Web sites allows innovation to be developed in an organization.

The use of Web sites allows government employees to share knowledge, to promote knowledge transfer and mobilize resources. Knowledge can be viewed as a result with learning as the process leading to this result. Innovation is largely an organizational property with an intimate relationship between knowledge and learning. CVSOs should keep learning by using Web sites to interact with other government agencies in order to better serve veterans [17]. Government should organize online training sessions to promote learning and knowledge updates of CVSOs in order to generate innovation. This suggests the following hypothesis:

H1: The website-supported learning and innovation perspective on a $\mathrm{G} 2 \mathrm{G}$ basis will have a positive effect on e-government service delivery performance.

\section{Website-Supported Internal Process Perspective}

Excellent customer performance derives from business processes, decisions, and actions that have the greatest impact on customer satisfaction [12]. Managers need to emphasize on these critical business processes occurring throughout a company. The internal business perspective of the $\mathrm{BSC}$ gives managers those internal measures [12].

Government units automate previously manual processes that are often the result of inefficient use of information resources in a government agency. These might need the public sector to reinvent and reengineer processes and procedures throughout government. This reengineering should be realized simultaneously with the choice of appropriate Web site contents. Government should ensure that the Web site contents fit the requirement of the brand new internal business process used in the public sector. The use of Web sites may render compatible the internal business process of cooperative government agencies. Thus, we propose the hypothesis below (see Figure 1):

$\mathrm{H} 2$ : The website-supported internal process perspective on a $\mathrm{G} 2 \mathrm{G}$ basis will have a positive effect on e-government service delivery performance.

\section{Website-Supported Veteran Value Proposition Perspective}

The most important aspect of any business strategy is the customer value proposition, which describes the unique mix of product and service attributes, customer relations, and corporate image that a company offers $[11,13]$. In the public sector, it defines how government will differentiate itself from businesses to attract, retain, and deepen relationships with other government agencies. By identifying its veteran value proposition, government will know which classes and types of agencies to partner with. CVSOs should play better roles of veteran advocacy when they use Web sites to interact.

Government units may partner with other government service providers. Electing to use Web sites to deliver services expands the amount and kind of data the partners can exchange. This enhances the collaborative activities among government agencies and their constituents. This intimacy will allow governments to stress the 
quality of its relationships with agencies, including exceptional public service and the completeness of the solutions it offers. Accordingly, it is hypothesized that (see Figure 1),

H3: The website-supported veteran value proposition perspective on a $\mathrm{G} 2 \mathrm{G}$ basis will have a positive effect on e-government service delivery performance.

\section{Website-Supported Financial Perspective}

When private companies build their strategy, they start with a financial strategy for increasing shareholder value [11]. Government units often put their citizens or constituents -- not the financials -at the top of their strategy maps [11].

Companies have two basic levers for their financial strategy: revenue growth and productivity [11]. Governments also have the same two levers because they are always trying to design new services and to increase veteran value by deepening relationships with other government employees. The productivity strategy is crucial for public service because governments and their constituencies need to improve their cost structure by reducing direct and indirect expenses related to service delivery to veterans. In general, those two basic levers contribute to the opportunities for enhancing financial performance.

The challenge for the usability of a Web site is to offer services that lock-in the government units and their partners. If the government units and government service providers decide to switch to a different Web site, not only will they incur switching costs due to organizational lock-in but also the switching costs that stem from retiring from the present Web site. Another challenge of the use of Web site is to decrease the initial cost incurred by e-government service deliveries over time. Therefore, we propose the following hypothesis (see Figure 1):

H4: The website-supported financial perspective on a $\mathrm{G} 2 \mathrm{G}$ basis will have a positive effect on egovernment service delivery performance.

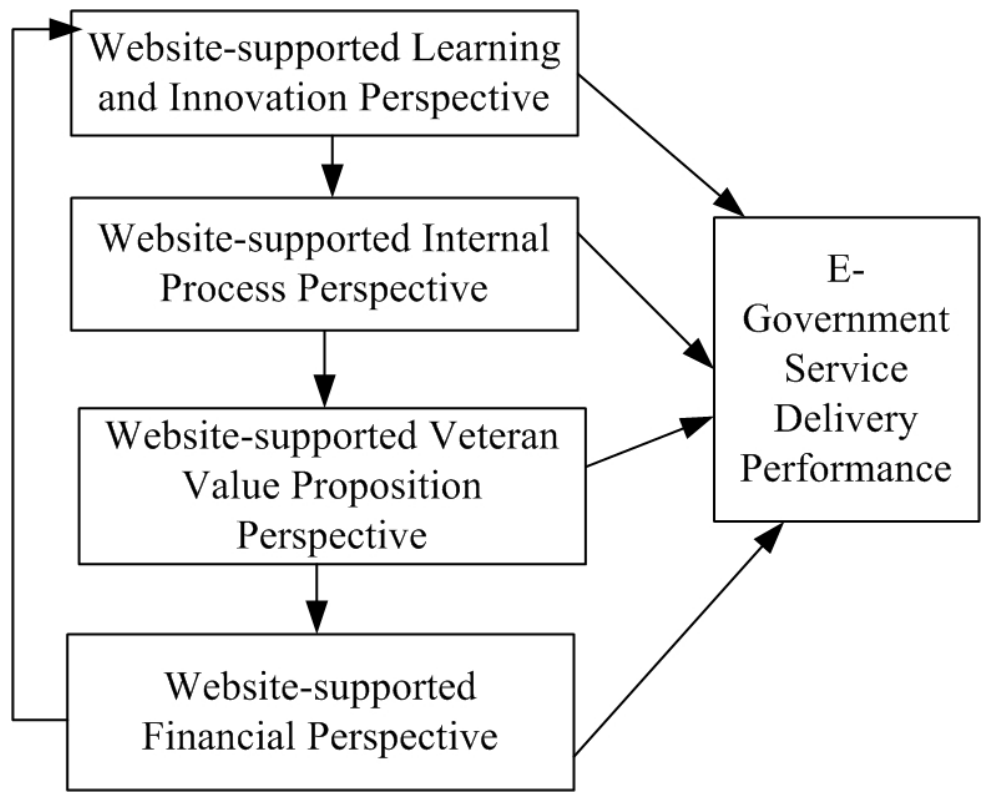

Figure 1. Research Model

\section{METHODOLOGY: MULTIPLE CASE STUDIES}

This research focuses on government Web sites that deliver electronic services to veterans. The Web site of the North Dakota Government Rural Outreach
(GRO) Initiative has been selected as the sample U.S. government Web site for this research. That Web site has been chosen because it has a component dedicated to veterans and CVSOs. 
The study used content analysis to analyze the data obtained from a sample of 19 CVSOs to test the hypotheses. Content analysis is a research technique for making replicable and valid references from data to their contexts. As content analysis can provide knowledge about concepts which are not directly observable, it is, therefore, appropriate for this study. Further, content analysis is context sensitive, thereby enabling us to process the symbolic forms of the Internet phenomenon.

The common response is obtained by using the generalized answers from all CVSOs. The procedure for data analysis was based upon totaling the overall counts of messages coded in each category and the analysis of the messages. Each research factor or variable has played the role of category. Occurrences of the messages in each category have been analyzed to determine their relative importance. Higher relative counts reflected the significance of the particular message within the specific category.

The sample of 19 CVSOs participated in the multiple case studies. They were interviewed for one hour, and those open-ended interviews were recorded on tape. To help conduct the interviews, an interview guide was used.

In this research, chi-square, a non-parametric test of statistical significance for bivariate tabular analysis, was used to test hypotheses.

\section{RESULTS}

Impact of Website-Supported Learning and Innovation on e-Government Service Delivery Performance

As shown in Table 1, the hypothesis which states that the website-supported learning and innovation perspective on a G2G basis will have a positive effect on e-government service delivery performance, was significant $(63.56$ at $\mathrm{p}<0.001)$. The test of this hypothesis confirms that CVSOs are willing to learn and innovate. It also shows that because every case is different and every county is different, it is important to have guidelines and instructions CVSOs may refer to when working online. Another argument which explains the positive impact of this hypothesis is the importance of the CVSOs to exchange information and share experiences among themselves and government agencies. Those initiatives contribute to their learning and innovation through increased levels of knowledge sharing.

Website-supported learning and innovation perspective can facilitate the dissemination of knowledge across government units, even to the point of making virtual teams a viable alternative to face-to-face work [9]. The use of the interactive Web site stabilizes the relationship between governments and CVSOs when it comes to the transfer of knowledge. Website-supported learning and innovation may provide a means of structuring teamwork, enhance the information available to the team, and provide a communication system. Website-supported learning and innovation may also create information where it did not exist before for teams of CVSOs and other government employees. Those teams may be formed regardless of the physical location of the employees, providing further opportunity and flexibility in building the best skilled, most knowledgeable and most motivated teams. The reduction in physical and temporal boundaries subsequently diminishes the likelihood that homogenous teams are formed for convenience, and also diminishes factors that might co-locate members in either space or time [9].

Website-supported learning and innovation may allow knowledge to be effectively transferred through training of government employees and CVSOs. Those virtual teams may transmit knowledge to their teammates, and their knowledge will be stored in a permanent knowledge base. Government executives may use that permanent knowledge base to empower their employees, particularly their new employees and CVSOs. Empowerment is defined as the process governments adopt to encourage and reward employees who exercise initiative and make valuable creative contributions, or do everything that is possible to help veterans solve their problems. CVSOs who are dedicated to treating the veterans well deliver superior value to veterans. The government's knowledge base protected by a secured firewall can be used through Web sites to enhance communication and collaboration among authorized employees. Only authorized government employees are able to use this because they are limited to information pertinent to the government and veterans. 
Table 1. Number, Percent, and Chi-square of learning and innovation

\begin{tabular}{|c|c|c|c|c|}
\hline $\begin{array}{c}\text { Coded } \\
\text { Messages }\end{array}$ & Number & $\begin{array}{c}\text { Percentage } \\
(\%)\end{array}$ & $\begin{array}{l}\text { Number of } \\
\text { CVSOs }\end{array}$ & $\begin{array}{c}\text { Chi- } \\
\text { Square }\end{array}$ \\
\hline IIKL & 34 & 81 & 16 & \multirow{3}{*}{$16.09^{* * *}$} \\
\hline IIKLN & 8 & 19 & 3 & \\
\hline Total & 42 & 100 & 19 & \\
\hline WTST & 18 & 29 & 7 & \multirow[t]{3}{*}{$10.90 * * *$} \\
\hline WTSTN & 44 & 71 & 12 & \\
\hline Total & 62 & 100 & 19 & \\
\hline BEDE & 41 & 89 & 16 & \multirow[t]{3}{*}{$28.17 * * *$} \\
\hline BEDEN & 5 & 11 & 2 & \\
\hline Total & 46 & 100 & 18 & \\
\hline IHTM & 15 & 43 & 6 & \multirow{3}{*}{0.71} \\
\hline IHTMN & 20 & 57 & 8 & \\
\hline Total & 35 & 100 & 14 & \\
\hline TSTR & 23 & 74 & 10 & \multirow{3}{*}{$7.25^{* *}$} \\
\hline TSTRN & 8 & 26 & 3 & \\
\hline Total & 31 & 100 & 13 & \\
\hline IHSA & 20 & 56 & 5 & \multirow[t]{3}{*}{0.44} \\
\hline IHSAN & 16 & 44 & 7 & \\
\hline \multirow{2}{*}{\multicolumn{4}{|c|}{ 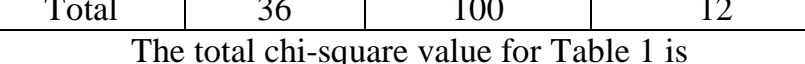 }} & \\
\hline & & & & $63.56 * * *$ \\
\hline
\end{tabular}

\section{Impact of Website-Supported Internal Process Perspective on e-Government Service Delivery Performance}

The results presented in Table $2(41.02$ at $\mathrm{p}<0.001)$ support hypothesis 2 , which states that the websitesupported internal process perspective on a $\mathrm{G} 2 \mathrm{G}$ basis will have a positive effect on e-government service delivery performance. This is not surprising when taking into account that, for example, in disability compensation or pension claims, CVSOs work through organizations to make contact with the VA. CVSO's work is then continuing internal processes. Pension claims or disability compensation is one of CVSOs' internal processes. Each internal process has an initial and ending step and produces an effective result. All the internal processes are not the same. Some are long and take too much time to perform because of their complexity. One of the most frequently used internal processes is the way CVSOs analyze and discuss the veterans' claims with the VA and other government agencies. CVSOs also work together on some internal processes. Another internal process consists of the long interactions CVSOs usually have with the medical industry and the series of signatures involved with regards to releasing information. The focus is on optimizing quality and time attributes of each electronic service delivery process. Manual and batched working processes are often the result of inefficient use of information resources in government agencies. This finding confirms the assertion that Web sites can be deployed to increase the level of information sharing and automate previously manual processes. Government units will provide the automated service delivery to veteran service providers and veteran representatives.

The effective usability of website-supported internal process perspective requires the integration of Web sites into existing work processes of government agencies. That integration might 
necessitate changes to current work processes. Michael Hammer advocated the use of IT to make radical changes in business processes [20], and many firms followed Hammer's ideas. Governments also followed Hammer's advice when they designed e-government service delivery projects. E-government occurred simultaneously with movements within the public sector to reinvent and reengineer processes and procedures throughout the government [18]. To gain a better understanding of e-government's service delivery potential, Gassan et al. [7] examined major initiatives around the world. They found that the real value of e-government derives less from simply placing public services on-line than from the ability to force an agency to rethink, reorganize, and streamline their delivery before doing so, much as the redesign of core processes in the 1980s transformed many businesses.

Table 2. Number, Percent, and Chi-square of internal process

\begin{tabular}{|c|c|c|c|c|}
\hline $\begin{array}{c}\text { Coded } \\
\text { Messages }\end{array}$ & Number & $\begin{array}{c}\text { Percentage } \\
(\%)\end{array}$ & $\begin{array}{c}\text { Number of } \\
\text { CVSOs }\end{array}$ & $\begin{array}{c}\text { Chi- } \\
\text { Square }\end{array}$ \\
\hline IMSS & 35 & 78 & 12 & \multirow[t]{3}{*}{13.88 *** } \\
\hline IMSSN & 10 & 22 & 4 & \\
\hline Total & 45 & 100 & 16 & \\
\hline AFFG & 39 & 74 & 13 & \multirow[t]{3}{*}{$11.79 * * *$} \\
\hline AFFGN & 14 & 26 & 6 & \\
\hline Total & 53 & 100 & 19 & \\
\hline WHRS & 31 & 63 & 10 & \multirow[t]{3}{*}{$3.44 *$} \\
\hline WHRSN & 18 & 37 & 7 & \\
\hline Total & 49 & 100 & 17 & \\
\hline WHAI & 20 & 44 & 9 & \multirow[t]{3}{*}{0.55} \\
\hline WHAIN & 25 & 56 & 8 & \\
\hline Total & 45 & 100 & 17 & \\
\hline HSWI & 40 & 73 & 13 & \multirow[t]{3}{*}{11.36 *** } \\
\hline HSWIN & 15 & 27 & 6 & \\
\hline Total & 55 & 100 & 19 & \\
\hline \multicolumn{4}{|c|}{ The total chi-square value for Table 2 is } & $41.02 * * *$ \\
\hline
\end{tabular}

\section{Impact of Website-Supported Veteran Value Proposition Perspective on e-Government Service Delivery Performance}

The results presented in Table 3 (33.72 at $p<0.001)$ confirm hypothesis 3 that the website-supported veteran value proposition perspective on a $\mathrm{G} 2 \mathrm{G}$ basis will have a positive effect on e-government service delivery performance. This hypothesis corroborates much of the following information collected during the interviews. CVSOs are building and maintaining working partnerships with other government agencies such as when they interacting with social security services. CVSOs also establish working relationships with government agencies when they initiate personal contact in order to serve veterans. Regular interaction or even opening a claim can be an opportunity for CVSOs to create intimate relationships with government agencies.

Electing to use Web sites to deliver services expands the amount and kind of data the partners can exchange [18]. This enhances the collaborative activities among government agencies and their constituents, allowing them to participate in a dynamic service delivery relationship where mutual beneficial information can be shared [10]. Finally, allowing and facilitating governments' units and their constituents to share and access critical service information using Web sites would be an important way for them to build relationships with each other. 
Table 3. Number, Percent, and Chi-square of veteran value proposition

\begin{tabular}{|c|c|c|c|c|}
\hline $\begin{array}{l}\text { Coded } \\
\text { Messages }\end{array}$ & Number & $\begin{array}{l}\text { Percentage } \\
(\%)\end{array}$ & $\begin{array}{l}\text { Number } \\
\text { of CVSOs }\end{array}$ & Chi-Square \\
\hline IGEV & 36 & 69 & 12 & \multirow[t]{3}{*}{$7.69 * * *$} \\
\hline IGEVN & 16 & 31 & 7 & \\
\hline Total & 52 & 100 & 19 & \\
\hline IWAT & 29 & 59 & 10 & \multirow[t]{3}{*}{1.65} \\
\hline IWATN & 20 & 41 & 9 & \\
\hline Total & 49 & 100 & 19 & \\
\hline ISIA & 27 & 67 & 11 & \multirow[t]{3}{*}{$4.9 *$} \\
\hline ISIAN & 13 & 33 & 6 & \\
\hline Total & 40 & 100 & 17 & \\
\hline IGUA & 38 & 70 & 13 & \multirow[t]{3}{*}{$8.96 * * *$} \\
\hline IGUAN & 16 & 30 & 6 & \\
\hline Total & 54 & 100 & 19 & \\
\hline ILGC & 18 & 35 & 8 & \multirow[t]{3}{*}{$4.92 *$} \\
\hline ILGCN & 34 & 65 & 11 & \\
\hline Total & 52 & 100 & 19 & \\
\hline WIDO & 15 & 33 & 7 & \multirow[t]{3}{*}{$5.56^{* *}$} \\
\hline WIDON & 31 & 67 & 10 & \\
\hline Total & 46 & 100 & 17 & \\
\hline \multicolumn{4}{|c|}{ The total chi-square value for Table 3 is } & $33.72 * * *$ \\
\hline
\end{tabular}

\section{Impact of Website-Supported Financial Perspective on e-Government Service Delivery Performance}

As shown in Table 4, the hypothesis that the website-supported financial perspective on a $\mathrm{G} 2 \mathrm{G}$ basis will have a positive effect on e-government service delivery performance was found to be negative ( 35.77 at $\mathrm{p}<0.001$ ) in the early stages of the implementation. However, as time goes on, that hypothesis was found to be positive $(25.53$ at $\mathrm{p}<0.001)$. The test of this hypothesis confirms that the perception of CVSOs using Web sites to decrease or increase the cost of delivering egovernment services varies profoundly. CVSOs believe that the initial cost is high but as time goes on that cost will decrease. The cost savings by using the Internet will be achieved over time. In addition, when using Web sites, CVSOs recognized improvements in terms of response time, ability to work together, access of information, communication, and error reduction.
When CVSOs continuously used Web sites to perform veteran benefit claims, they should increase their sense of belonging to the Web sites. Therefore, switching to a different Web site does not only mean getting used to a different user interface, a new set of services, and going through the agony of customizing the new Web site, it also means abandoning a community of friends and partners. Lock-in effects capture the idea that the delivery of certain services through Web sites soon becomes a habit that is hard to break. When Web sites become well known to the CVSOs, they no longer pay attention to them or the dependency they developed [4]. The challenge for a Web site is to offer services that lock-in the government units, veteran representatives and government service providers. The design and the composition of the Web site user interface and services may allow government employees to become dependent on them for seamlessly navigating the Internet. If the 
government units, veteran representatives and government service providers decide to switch to a different Web site not only will they incur switching costs due to organizational lock-in, but they will experience switching costs that stem from retiring from the present Web site.

Table 4. Number, Percent, and Chi-square of financial perspective

\begin{tabular}{|c|c|c|c|c|}
\hline $\begin{array}{c}\text { Coded } \\
\text { Messages }\end{array}$ & Number & $\begin{array}{c}\text { Percentage } \\
(\%)\end{array}$ & $\begin{array}{c}\text { Number } \\
\text { of CVSOs }\end{array}$ & Chi-Square \\
\hline TUIS & 30 & 56 & 10 & \multirow[t]{3}{*}{0.66} \\
\hline TUISN & 24 & 46 & 8 & \\
\hline Total & 54 & 100 & 18 & \\
\hline TDWE & 15 & 29 & 6 & \multirow[t]{3}{*}{$8.64 * * *$} \\
\hline TDWEN & 36 & 71 & 12 & \\
\hline Total & 51 & 100 & 18 & \\
\hline & & & & \multirow[t]{4}{*}{$5.81 * *$} \\
\hline TIWA & 30 & 68 & 11 & \\
\hline TIWAN & 14 & 32 & 6 & \\
\hline Total & 44 & 100 & 17 & \\
\hline & & & & \multirow{4}{*}{$10.25 * * *$} \\
\hline ICIM & 32 & 74 & 12 & \\
\hline ICIMN & 11 & 26 & 5 & \\
\hline Total & 43 & 100 & 17 & \\
\hline & & & & \multirow[t]{4}{*}{$11.07 * * *$} \\
\hline IDSC & 14 & 27 & 6 & \\
\hline IDSCN & 38 & 73 & 13 & \\
\hline Total & 52 & 100 & 17 & \\
\hline & & & & \multirow[t]{4}{*}{0.55} \\
\hline TMTS & 20 & 44 & 10 & \\
\hline TMTSN & 25 & 56 & 9 & \\
\hline & 45 & 100 & 19 & \\
\hline \multicolumn{4}{|c|}{ The total chi-square value is } & $35.77 * * *$ \\
\hline & & & & \multirow[t]{4}{*}{$15.29 * * *$} \\
\hline TILE & 42 & 76 & 13 & \\
\hline TILEN & 13 & 24 & 6 & \\
\hline Total & 55 & 100 & 19 & \\
\hline & & & & \multirow[t]{4}{*}{$10.24 * * *$} \\
\hline IDTA & 20 & 30 & 9 & \\
\hline IDTAN & 46 & 70 & 10 & \\
\hline Total & 66 & 100 & 19 & \\
\hline \multicolumn{4}{|c|}{ The total chi-square value is } & $25.53 * * *$ \\
\hline
\end{tabular}

CONCLUSION

Theoretical and Managerial Implications
The significance of aligning Web sites with government strategy is well noted by researchers. The lack of appropriate methodologies has 
prevented government units from integrating $\mathrm{Web}$ site projects effectively with e-government service delivery performance. Our proposal about the government use of website-supported BSC framework is intended to address this issue. Based on this framework, a content analysis approach is used to analyze the message contained in data collected from a sample of 19 CVSOs. The results show that the different aspect of the profession of CVSOs fits with the four interrelated BSC factors.

The results also show that website-supported BSC three perspectives (learning and innovation, internal process, and veteran value proposition) have a positive impact on e-government service delivery performance. The website-supported financial perspective has a negative impact on e-government service delivery performance in the early stage of the implementation of the Web sites. However, as time goes on, that impact will become positive because the high initial cost will decrease over time. Finally, the results show that, at any time of the usability, the websites-supported BSC factors have a positive impact on e-government service delivery performance in terms of response time, ability to work together, access to information, communication, and error reduction. The main obstacle to the usability of Web sites among CVSOs seems to be the lack of motivation about the real advantages these technologies could add to their profession and, more generally, the culture and resistance to change that characterizes government employees.

The results of this study will allow Internet and information systems experts to inform government agencies and CVSOs the ways to identify the most valuable and rigorous Web site initiatives for their specific e-service delivery strategies. They should also provide a basis for justifying and evaluating Web site investment initiatives.

Existing research has developed models that combined both BSC and e-government concepts. This study expands the BSC theory and applies it to the e-government service delivery performance on a G2G basis.

\section{Limitations}

There are several limitations of this study. Firstly, the study focuses on only one state (CVSOs in North Dakota) and it remains to be seen if the results apply to other states. This may restrict the generalizability of the findings. Secondly, there were limitations concerning the interview guide used, as related to the profile of respondents. From certain statements, we became aware that some interviewees did not necessarily have a sound knowledge of the government Web sites. In addition, some responses were based on respondents' opinions and subjective perceptions and not on objective data.

\section{Future Research}

Further research is necessary as Internet technology is evolving so rapidly. It is important for future studies to test and enhance the frameworks. Future empirical studies in the form of quantitative studies should be undertaken to determine how government units deploy Web sites or Web portals strategically as measured by the BSC. Finally, further research should also expand the range of Web site characteristics and examine their effects on egovernment service delivery security.

\section{REFERENCES}

1. Bhagwat B. \& Sharma M. K. (2007). Performance measurement of supply chain management: A balanced scorecard approach, Computers \& Industrial Engineering, Vol 53, pp. 43-62.

2. Cetiner, M. and Ryan, T. (2004). How to improve the usability of government web sites. Proceedings of the Seventh Conference of the Southern Association for Information Systems. $1(1), 65-68$

3. Chen, H-J and Lin, T-C (2007). Exploring source of the variety in organizational innovation adoption issues - An empirical study of managers' label on knowledge management project issues in Taiwan, Expert Systems with Applications, Vol. 36, No. 2, pp. 1380-1390.

4. Damsgaard, J. (2002). Managing an Internet Portal. Communications of the Association for Information Systems, 8(9), 408-420.

5. Dufner, D., Holley, L., and Reed, B. (2002). Can private sector strategic information systems planning techniques work for the public sector? Communications of the Association for Information Systems, 8(27), 413-431. 
6. Edgington, T. and Chen, A. (2002). An economic Benefit Model for Knowledge Creation. Proceedings of the Twenty-Third International Conference on Information Systems. 1(1), 583-592.

7. Gassan, A., De Boer, K., Mourshed, M. and Rea, P. (2001). Putting Citizens on-line, not in line. The McKinsey Quarterly, Number 2. Online tactics.

8. Gilbert, D., Balestrini, P. and Littleboy, D. (2004) Barriers and benefits in the adoption of e-government. International Journal of Public Sector Management, Vol. 17, pp. 286-301.

9. Griffith, T., Sawyer, J., and Neale, M. (2003). Virtualness and Knowledge in Teams: Managing The Love Triangle of Organizations, Individuals, and Information Technology. MIS Quarterly. 2(27), 265-287.

10. Huang, D. C, and Hu, Q. (2004). Integrating web services with competitive strategies: The balanced Scorecard approach. Communications of the Association for Information Systems, 1(13), 57-80.

11. Kaplan, Robert S., Norton, David P., (2000). Having Trouble with Your Strategy? Then Map It , Harvard Business Review, Vol. 78, Issue 5

12. Kaplan, Robert S., Norton, David P., (1992) The Balanced Scorecard - Measures That Drive Performance. Harvard Business Review. P. 71-79.

13. Lombard, M., and Ditton, T. (1997). At the heart of it all: The concept of presence. Journal of Computer-Mediated Communication [Online],3 (2). Available: 47. http://www.ascusc.org/jcmc/vol3/issue2/lomba $\underline{\text { rd.html }}$

14. Moon, M. J. (2002). State Government EProcurement in the Information Age: Issues, Practices, and Trends. E-Government Series, 165.

15. Papalexandris, A., Ioannou, G., Prastacos, G., \& Soderquist, K., E. (2005). An Integrated Methodology for Putting the Balanced Scorecard into Action, European Management Journal, Vol. 23, No. 2, pp. 214-227.

16. Prybutok V. R., Zhang X. and Ryan S. D. (2008). "Evaluating leadership, IT quality, and net benefits in an e-government environment" Information and Management, Vol. 45, pp. 143-152.

17. Rafaeli, S., and Sudweeks, F. (1997). Networked interactivity. Journal of ComputerMediated Communication [On-line], 2 (4). Available:http://www.ascusc.org/jcmc/vol2/iss $\underline{\text { ue} 4 / \text { rafaeli.sudweeks.html }}$

18. Stowers, G. N. L. (2004). Measuring the Performance of E-Government. E-Government Series, 1-52.

19. Wong-On-Wing, B., Guo, L., Li, W. \& Yang, D. (2007). Reducing conflict in balanced scorecard evaluations, Accounting Organization and Society, Vol. 32, pp. 363377.

20. Wright, W., Smith, R., Jesser, R., and Stupeck, M. (1999). Information Technology, Process Reengineering and Performance Measurement: A Balanced Scorecard Analysis of Compaq Computer Corporation. Communications of the Association for Information Systems, 8(1), 1-

\section{APPENDIX}

Table 5. Learning and innovation perspective

\begin{tabular}{|l|l|}
\hline $\begin{array}{l}\text { Coded } \\
\text { Messages }\end{array}$ & Definition of Messages \\
\hline IIKL & I figure I keep learning. \\
\hline IIKLN & There is not always something I can learn. \\
\hline & \\
\hline WTST & We have the training sessions twice a year but they do not help us because too complex \\
\hline
\end{tabular}




\begin{tabular}{|c|c|}
\hline WTSTN & $\begin{array}{l}\text { We have the training sessions twice a year and they are helpful because the organizers take } \\
\text { into account our feedback }\end{array}$ \\
\hline BEDE & $\begin{array}{l}\text { Because every case is different, and every county is different we exchange our experience } \\
\text { when we get together }\end{array}$ \\
\hline BEDEN & $\begin{array}{l}\text { Because every case is different, and every county is different, sharing our experience when } \\
\text { we get together doesn't help }\end{array}$ \\
\hline IHTM & I have a training module on my computer \\
\hline IHTMN & I do not have a training module on my computer \\
\hline TSTR & There's specialized training classes that comes from the department or the regional office \\
\hline TSTRN & All counties do not have specialized training classes that comes from the regional office \\
\hline IHSA & I have a self-assessment test that I can take on my computer \\
\hline IHSAN & Only new CVSOs have a self-assessment test that they can take on their computer \\
\hline
\end{tabular}

Table 6, Internal process perspective

\begin{tabular}{|l|l|}
\hline $\begin{array}{l}\text { Coded } \\
\text { Messages }\end{array}$ & Definition of Messages \\
\hline IMSS & $\begin{array}{l}\text { I make suggestions to our commissioners to make them aware about how the process is, } \\
\text { what the initial step should be taken in the process. }\end{array}$ \\
\hline IMSSN & I let the commissioners understand why it takes time to do the process \\
\hline & \\
\hline AFFG & After filling out the forms, I send the form to government agencies. \\
\hline AFFGN & After filling out the forms, veterans send the form to government agencies. \\
\hline & \\
\hline WHRS & We have some reference material that we can refer to and so on. \\
\hline WHRSN & We have some reference material that we can refer but they are too difficult to understand. \\
\hline & \\
\hline WHAI & We have an ability now with Internet to assist each other \\
\hline WHAIN & We have to do a lot more signatures but Internet does not allow that \\
\hline & \\
\hline HSWI & Having stuff online would save some phone calls and some inquiring. \\
\hline HSWIN & I make phone calls and have conversations before finding out solutions to problems. \\
\hline & \\
\hline
\end{tabular}

Table 7. Veteran value proposition perspective

\begin{tabular}{|l|l|}
\hline $\begin{array}{l}\text { Coded } \\
\text { Messages }\end{array}$ & Definition of Messages \\
\hline IGEV & $\begin{array}{l}\text { I always get new contacts in order to get things done quicker and that makes us easier to work } \\
\text { for the veterans. }\end{array}$ \\
\hline IGEVN & Government agencies always initiate contacts with me \\
\hline IWAT & $\begin{array}{l}\text { I establish working relationships through personal contact, phone conversations, direct } \\
\text { questions that they may ask, anything related to that }\end{array}$ \\
\hline IWATN & Government agencies usually establish working relationship with me \\
\hline ISIA & $\begin{array}{l}\text { I share information with government agencies by giving them information, so they know what } \\
\text { is available }\end{array}$ \\
\hline ISIAN & Government agencies share information with me by providing information that is available \\
\hline
\end{tabular}




\begin{tabular}{|l|l|}
\hline IGUA & $\begin{array}{l}\text { I give to government agencies what they do not really know to keep them updated about } \\
\text { changes }\end{array}$ \\
\hline IGUAN & Government agencies give me what I really need to keep me updated about changes \\
\hline & \\
\hline ILGC & I have long-going relationship anytime a claim is open. \\
\hline ILGCN & $\begin{array}{l}\text { I do not wait until a claim is open before building partnership relationship with government } \\
\text { agencies. }\end{array}$ \\
\hline WIDO & We are all able to share information during open house. \\
\hline WIDON & $\begin{array}{l}\text { Once you know these people they'll all go out of their way to help so it's the teamwork that } \\
\text { really works }\end{array}$ \\
\hline & Total \\
\hline
\end{tabular}

Table 8. Financial perspective

\begin{tabular}{|c|c|}
\hline $\begin{array}{ll}\text { Coded } \\
\text { Messages }\end{array}$ & Definition of Messages \\
\hline TUIS & The use of the Internet will cut a lot of time and save a lot of than the use of mail system. \\
\hline TUISN & $\begin{array}{l}\text { The Internet is quicker, faster, and cheaper but a lot of organizations do not want to use it, } \\
\text { because they want original signature. }\end{array}$ \\
\hline TDWE & $\begin{array}{l}\text { The use of the Internet may decrease the cost because it would limit the cost of the paper and } \\
\text { the number of the forms. There would not be that many errors. }\end{array}$ \\
\hline TDWEN & I don't know if it will decrease the initial cost that much \\
\hline TIWA & The use of the Internet will increase definitely our ability \\
\hline TIWAN & $\begin{array}{l}\text { If I can not get the information from the internet, I will make a phone call, and asked 'can you } \\
\text { send me the information or can I talk to you now }\end{array}$ \\
\hline ICIM & I use Internet to communicate medical information faster than the mails \\
\hline ICIMN & You can't get of the paper, I don't think completely. The internet certainly expedites things. \\
\hline IDSC & It decreases somebody's cost, and adds to somebody else's cost. \\
\hline IDSCN & $\begin{array}{l}\text { One thing that I see is that it would be a huge financial benefit would be the service officers } \\
\text { could submit an informal claim via the Internet to the VA on behalf of a veteran or a widow }\end{array}$ \\
\hline TMTS & $\begin{array}{l}\text { The use of the Internet may decrease the cost, at the same time it may increase the cost } \\
\text { because there is no security. }\end{array}$ \\
\hline TMTSN & $\begin{array}{l}\text { The use of the Internet may decrease the cost because it lets me find more medical information } \\
\text { and saved medical record about veterans }\end{array}$ \\
\hline TILE & $\begin{array}{l}\text { The use of the Internet may work out in the long-run because it will be cheaper when they get } \\
\text { everything }\end{array}$ \\
\hline TILEN & $\begin{array}{l}\text { The initial cost is going to be expensive though. But I do not think as time goes on it will be } \\
\text { less and less expensive }\end{array}$ \\
\hline IDTA & $\begin{array}{l}\text { I do not think the Internet will change the costs of the government services at all in the long } \\
\text { term. }\end{array}$ \\
\hline IDTAN & $\begin{array}{l}\text { I've looked up pension rates, compensation and pension rates of the past on the Internet, keep } \\
\text { track of different policies, you know, VA policies, that's helped me as a service officer. It why } \\
\text { I think, it will decrease the long term cost. }\end{array}$ \\
\hline
\end{tabular}

